\title{
Hashtags as Crowdsourcing: A Case Study of Arabic Hashtags on Twitter
}

\author{
Batool Hendal \\ Department of Information Studies, College of Social Studies, Kuwait University, Kuwait City, Kuwait \\ Email: Batool.hindal@ku.edu.kw
}

How to cite this paper: Hendal, B. (2019) Hashtags as Crowdsourcing: A Case Study of Arabic Hashtags on Twitter. Social Networking, 8, 158-173.

https://doi.org/10.4236/sn.2019.84011

Received: August 4, 2019

Accepted: October 27, 2019

Published: October 30, 2019

Copyright (C) 2019 by author(s) and Scientific Research Publishing Inc. This work is licensed under the Creative Commons Attribution International License (CC BY 4.0).

http://creativecommons.org/licenses/by/4.0/

\begin{abstract}
This mixed study aims to highlight the impact of social media in the Arab world, specifically Twitter's impact on translators' communities. For this purpose, the role of hashtags among translators will be examined by investigating one particular Arabic hashtag, its purpose, target users, and the classification of content. The hashtag is المترجم_في_خمة_المترجم\#, \#translator_serving_translator. 1) An online survey of six closed questions was employed and posted on Twitter, and 249 responses show that users are from fourteen Arab countries, and the majority is from Saudi Arabia. Hashtag users are translators, freelancers, or TS students. Some are active users who post tweets and answer questions, others only ask questions, and the rest only read tweets. The general attitude toward employing hashtags among translators' communities was positive. 2) Employing a content analysis approach, the content is classified into two main categories of sharing information and seeking assistance with seven subcategories of each.
\end{abstract}

\section{Keywords}

Hashtag, Twitter, Social Media, Translators, Crowdsourcing, Translation Studies, Twitter Content Classifications

\section{Introduction}

The last decade of the 20th century involved a revolutionary shift in technology, information, and the nature of media that challenged traditional sources of information and communication and transformed them forever. Today, the Internet, social media, and the digital revolution all help in shaping the media scene for the new century. Screens have replaced the printed page, be it in the form of newspapers, books, magazines, diaries, letters, or even billboards [1]. The recent technological developments, and social media specifically, have altered how 
people communicate and obtain information, and translators were not excluded.

Social media opened a vast area of academic research as a main subject, and each social media platform-Facebook, Twitter, LinkedIn, and so on-is a fertile ground for studies in education, linguistics, and communication. In translation studies (TS) and linguistics in general, social media have gained more attention recently. During the last 5 years, according to Desjardias [2], there has been a significant rise in the number of publications and conferences addressing translation and social media. The most important topic in this field was the effect of technology and globalization on language [3]. Other scholars have highlighted the impact of the web and technology on translation as a field of study and as a profession (Bacalu, 2013 as cited in [2] [4]). Desjardias [2] added that all these researchers agreed that the web and online social media would continue to greatly influence the translation profession and its research.

Desjardias [5] examined three main areas of translation and social media. The first area was social media's impact on the nature of the texts and, accordingly, the skills that student translators must acquire based on the market demands.

The second aspect Desjardias [5] considered is the increase in new translation tools and reference materials as a result of the e-terminology involved in the Internet and in social media. Desjardias [5] claimed that crowdsourced dictionaries and wikis are also forms of social media, as they include user-generated content (e.g., Urban Dictionary). The third aspect Desjardias investigated is translators' networks; translators use these communities to market themselves and their services on social media outlets such as LinkedIn. Furthermore, social media allows translators to create virtual communities to discuss translation-related topics; these sites include https://www.proz.com and the Arabic Translation and Intercultural Dialogue Association. Internet and Web 2.0 tools facilitate the way people work and assist crowds of users to communicate and work from anywhere in the world, through professional networks where they can create and share knowledge. Crowdsourcing, in general, emphasizes user-generated content, sharing and interactivity [6]. There are several terms that overlap with crowdsourcing in addition to virtual community; "peer production, user-powered systems, user-generated content, collaborative systems, community systems, social systems, social search, social media, collective intelligence, wikinomics, crowd wisdom, smart mobs, mass collaboration and human computation" (p. 3 in [7]).

In this paper, one form of translators' networks-Crowdsourcing-will be examined. Translators create this own network in Twitter via hashtag labels, one particular hashtag will be investigated, including the users of this hashtag and their backgrounds, and the classification of topics discussed via this hashtag. This is the first study, based on the author's knowledge that explores the Arabic translators' hashtags, aiming at shedding the lights on the benefits and usages of this platform in serving translators.

\section{Twitter Hashtag}

Twitter is a social media outlet that millions of people worldwide use to connect 
with families, friends, and colleagues via computers and mobile phones. Twitter's mission is "to give everyone the power to create and share ideas and information instantly, without barriers" [8]. This microblogging platform has become a significant real-time information resource. Twitter users can post short messages (of up to 140 characters), and any Twitter user can read those messages. Twitter users can access basic data about other users, including the accounts that follow a user and the accounts that a user follows [9]. The most prominent feature of Twitter is its fast dissemination, which makes it an excellent place for posting experiences and sharing information immediately. Out of all social media networks, Twitter has achieved the strongest connection between ordinary people and popular, powerful, and rich people [10], while Zhao et al. [11] claimed that Twitter, as a microblogging service, has become popular and widespread because tweets are compact and can be read quickly, which has caused Twitter to be used to share breaking news, personal updates, and ideas.

According to https://twitter.com [12], the service has 328 million monthly active users, $82 \%$ of whom are on mobile. The total number of active users in the Arab world was about 5,797,500 as of March 2017, 40\% of whom are in Saudi Arabia (2,400,000 users); among the 17,198,900 tweets produced in the Arab world each day (as of March 2014), 40\% are produced by Saudi Arabia, followed by Egypt (17\%) and Kuwait (10\%) [13].

The hashtag feature, which was created on Twitter, can be included anywhere in a tweet. A hashtag-denoted with the \# symbol-is a shorthand convention adopted by Twitter users to manually assign their tweets to a wider corpus of posts on the same topic [14]. According to Small [15], a hashtag is a keyword, or keywords, assigned to information that describes a tweet. This hashtag helps in searching and in organizing information on Twitter, and it provides accurate and timely statistics about trending topics on Twitter. By clicking or tapping on a word or phrase with a hashtag in any post, other tweets with this hashtag will be displayed [12]. For example, someone interested in any topic, such as translation, can find hashtags related to translation, TS, translation CAT (Computer-Assisted Translation), and more. This function applies to all languages and to many social media applications in addition to Twitter, such as Instagram and Facebook. According to Radioum One-an online advertising company-almost $75 \%$ of social media users use hashtags [16]. In twitter, virtual user communities defined by hashtags are made to exchange information with other users using the same hashtag. A group of users using the same hashtag in their tweets are known as hashtag community [17].

\section{Translator Service Hashtag}

Translators' Crowdsourcing, as in many other professions, starts with using hashtags to label and organize their professional needs among themselves, including among Arab translators. In September 2016, Fahd Alhathlloul, an academic and professional translator and interpreter from Saudi Arabia, published a new hashtag that serves translator communities: 
\#translator_serving_translatorالمترجم_في_خدمة_المترج\#. As the label shows, this hashtag aims to offer assistance to other translators. After establishing this hashtag for more than 2 years, we will examine this hashtag. What type of assistance and topics can be presented via this hashtag? Who are the users? To what extent can Arab translators believe this hashtag, or any other hashtags that serve translators' communities?

\section{Methodology}

\subsection{Design}

To better understand the content and classifications of topics discussed in this hashtag, the users and their attitudes toward translators' hashtags in general and toward this hashtag in particular will be considered. For this purpose, a mixed approach will be conducted. This approach includes a qualitative content analysi to examine the tweets under this hashtag and a quantitative survey of six questions (in addition to the demographic questions) to observe the members of this crowdsourcing and their attitudes toward the hashtag.

\subsection{Quantitative Approach}

Using Google Forms, a closed-ended online questionnaire was designed in Arabic as the target audience was mainly Arabic. There are six main questions, in addition to the demographic information (sex, age, major, education level, and country).

- Why are you interested in translation (translator, TS student, freelancer, or translation fan)?

- Why are you using this hashtag (to ask questions, to participate and answer questions, only to browse/read)?

- Whom does this hashtag serve most (TS student, translators, or TS researchers)?

- What are the most frequently discussed topics (seven topics)?

- Do you think this hashtag is helping you?

- Do you recommend that translators use hashtags in Twitter or in other social media?

The questionnaire was posted in June 2018 on Twitter under the same hashtag, in cooperation with Mr. Alhathloul-the founder of this hashtag-to ensure the same users will be involved.

\subsection{Qualitative Approach}

To explore and classify the content of the hashtag tweets, a content analysis strategy will be employed. According to Vaismoradi [18], the content analysis is systematic coding and categorizing approach aims at investigating large amounts of textual information, in order to determine trends of the used words, their frequency and relationships, and to describe the characteristics of the documents' content. The achievement of this strategy's purpose is "by examining who says what, to whom, and with what effect" ([18], p. 400).

The corpus of this study is all the tweets during a random month under this 
hashtag المنرجم_في_خدمة_المنرجم. The corpus contains 496 Tweets from March 11, 2019 to April 11, 2019. The decision to choose a random sample was based on previous research by Kim, Jang, Kim, and Wan's examination of two methods of sampling Twitter content [19]. The first is the simple random sample method. Researchers use the simple random sample method by collecting all tweets from a particular period and then randomly selecting a particular number of tweets. In the second method, the constructed week sample, researchers select all the tweets from a particular day of the week, such as Monday, and then select one Monday out of all the available Mondays. By comparing the efficiency of the two methods, Kim et al. [19] found that the simple random sample method is more efficient and more representative for sampling Twitter content. Thus, constructed week sampling was avoided here, and all the tweets in the randomly selected month are involved in the content analysis.

Twitter advanced search and the Mediatoolkitwebsite were used to collect all the tweets under the hashtag. The latter, unlike Twitter, enables its users to download the selected tweets with details such as time, date, who tweeted it, the origin country, a content analysis of the tweets, and statistical reports with all the details of all the tweets from the selected period. However, the content analysis of the Mediatoolkitwebsite only categorized the tweets as negative, positive, and neutral. Because our aim is to classify the content of these tweets based on the topics discussed, we will manually examine the tweets to classify the content based on the main trends and information in the tweets. Dann's [20] Twitter content classification is adopted with some modifications based on the chosen tweets to match the focus of this study. Dann claims there are six main categories for Twitter content classifications:

a) Conversational: includes queries, referral, action, and responses.

b) Status: contains personal opinion or emotional status, temporal (dates and times), location, mechanical (technology), physical experiences, work, automated (e.g. games or software), and activities.

c) Pass along: involves retweeting, UGC (links to content produced by the user), and endorsement (links to content not created by the user).

d) News: includes headlines, sport news, event, and weather.

e) Phatic: contains greetings, fourth wall, broadcast, and unclassifiable (errors and half posted sentences, and finally.

f) Spam: tweets generated without users consent.

Accordingly, this paper's content will be classified based on these six categories, if applicable. Otherwise, the results will show if there are other categories or if some of Dann's categories are not included in this hashtag.

\section{Results}

\subsection{Hashtag-User Participants}

The study gained 249 responses from 195 females (78.3\%) and 54 males $(21.7 \%)$. The majority of the respondents, 117 (47\%), are in the 18- to 24-year-old age group, followed by the 25 - to 34 -year-old (39.8\%) and the 35 - to 44 -year-old, 
with 25 participants (10\%). The 45- to 54-year-old age group had 6 users $(2.4 \%)$, and the last group, 55- to 64 -year-old, had only 2 participants $(0.8 \%)$. There were no participants under 18 or over 65.

\subsection{Qualifications and Academic Status}

Most users, 183 (37.5\%), have a baccalaureate degree or are undergraduate students, $51(20.5 \%)$ respondents have a master's degree or are master's-level students, and $15(6 \%)$ of them have a $\mathrm{PhD}$ degree.

\subsection{Major}

Over a third of the contributors are from a TS major (35.7\%) or minor (24.1\%). The English linguistics major accounts for $11.6 \%$ of the contributors, English literature for $8.8 \%$, and French, English, education, and English and Literature ${ }^{1}$ account for the same percentage at $4.8 \%$. Finally, Arabic had the least participants, only two $(0.8 \%)$, and $4.4 \%$ selected others to refer to other disciplines.

\subsection{Country}

As Figure 1 shows, over $80 \%$ (216) of the participants were from Saudi Arabia, $2.4 \%$ (6) were from Syria, $2 \%$ (5) were from Morocco, $1.6 \%$ (4) were from Oman, 1.6\% (4) were from Bahrain, and 1.3\% (3) were from Yemen. Lebanon, Egypt, and Palestine each had 2 participants for $0.8 \%$, and Qatar, Jordan, Algeria, Iraq, and Somalia each had 1 participant for $0.4 \%$.

Each of the six questions provided multiple choices, and the answers and percentages were coded and acquired from Google Forms.

The first question dealt with why participants were interested in translation. As Figure 2 shows, the majority of participants (47\%) are interested in translation and TS in general. The next reason is because the participants (41\%) work as translators as their main job, followed by individuals who are attracted to translation as a hobby (29.7\%). Finally, the freelancers account for $27.7 \%$.

The second question dealt with why participants used the hashtag. Most respondents used this hashtag only to browse and read others' tweets without any interaction (69.9\%). Next, $28.5 \%$ of participants are active users who participate with questions. Finally, $45 \%$ of participants are more active users who participate-tweet under this hashtag — and answer the questions tweeted by others (Figure 3).

The third question deals with who is most served by the hashtag. The participants believe that this hashtag mostly serves TS students (70.7\%).The participants who $40.6 \%$ think it serves translators account for $40.6 \%$, and $28.1 \%$ think it helps TS researchers (Figure 4).

When asked about the more frequently discussed topics under this hashtag, most of the answers (76.7\%) pointed out that inquiries about translating particular terms or phrases are frequent among users (Figure 5). Professional tweets, including advice and information for translators, account for $65.9 \%$, followed by ${ }^{1}$ Some universities have different discipline titles and some disciplines were added to the survey based on participants' notes. 


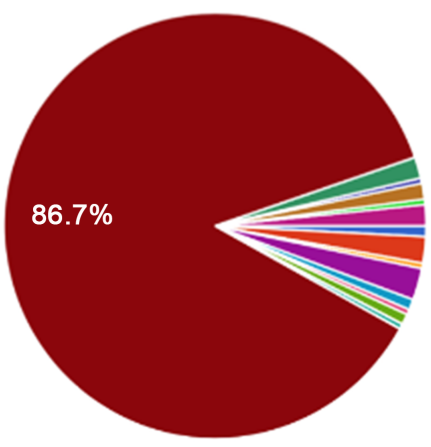

$\begin{array}{lll}\text { Egypt } & \text { Tunisia } & \text { UAE } \\ \text { Morocco } & \text { Libya } & \text { Oman } \\ \text { Iraq } & \text { Mauritania } & \text { Bahrain } \\ \text { Sudan } & \text { Somalia } & \text { Qatar } \\ \text { Syria } & \text { Djibouti } & \text { Yemen } \\ \text { Lebanon } & \text { Comoros } & \text { Algeria } \\ \text { Jordan } & \text { Kuwait } & \\ \text { Palestine } & \text { Saudi Arabia }\end{array}$

Figure 1. Chart of users' countries.

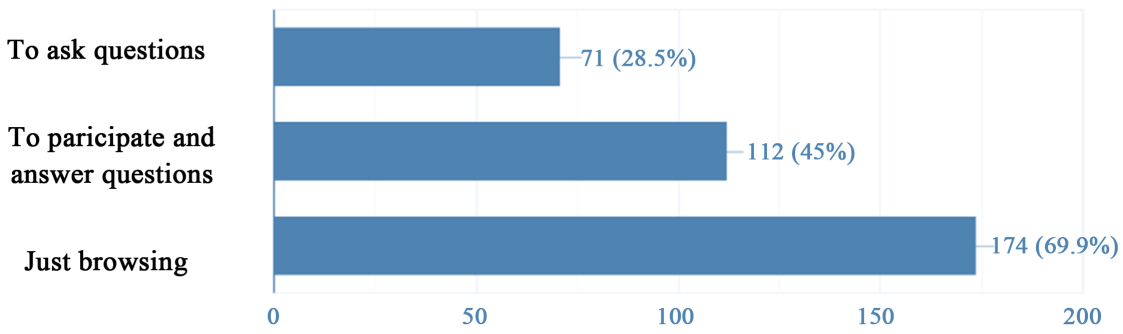

Figure 2. The answer for Q1.

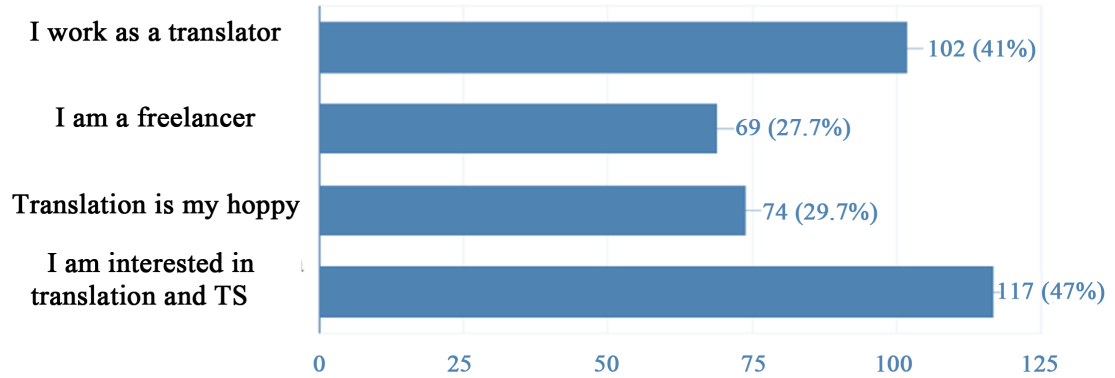

Figure 3. The answer for Q2.

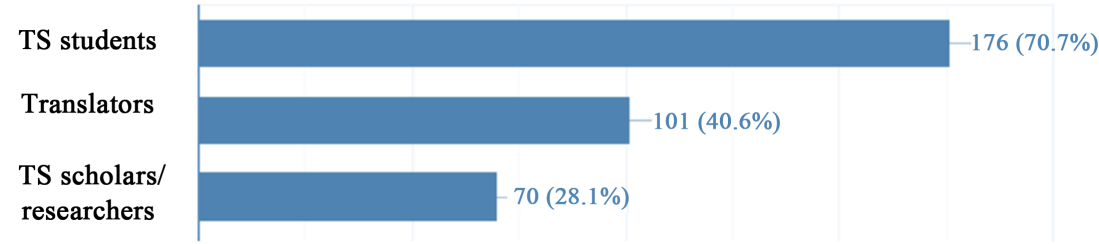

Figure 4. The answer for Q3.

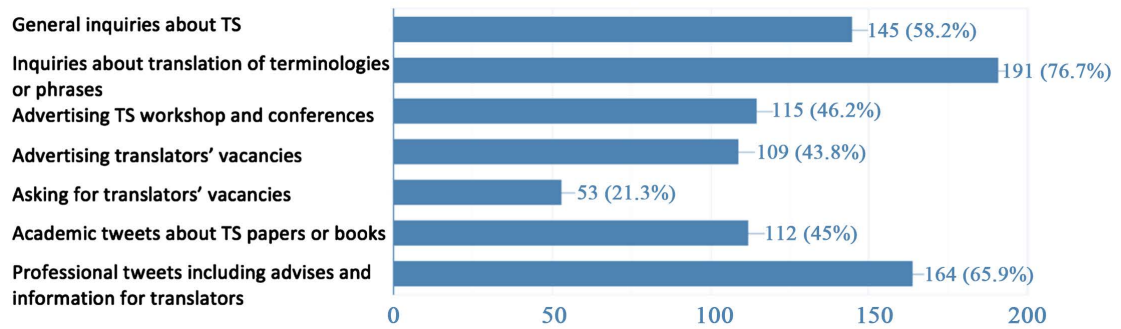

Figure 5. The answer for Q4. 
general questions about TS as a major. A relatively high number (46.2\%) think this hashtag advertises workshops and conferences related to TS. Next, $43.8 \%$ believe that the hashtag is used to advertise translator vacancies, and $21.3 \%$ think it is used to ask for vacancies. Finally, academic tweets also occur on this hashtag, including information about TS studies and books (45\%).

The next question dealt with how much participants thought the hashtag helped them. Employing a Likert Scale of five, the answers to this question reveal participants' attitude etowards this hashtag. The majority think this hashtag is helpful; $42.2 \%$ (105) believe it is very useful and $45.8 \%$ (114) agreed that it is useful. Additionally, $8.8 \%$ (22) were neutral, and $2.8 \%$ (7) think it was not useful. One person chose not useful at all (0.4\%; Figure 6).

When requested to give recommendations for using hashtags among translators' communities via Twitter or any other social media platform, $71.9 \%$ (179) of respondents strongly recommend using hashtags among translators' communities, $25.7 \%$ (64) agreed, and 2.4\% (6) were neutral (Figure 7).

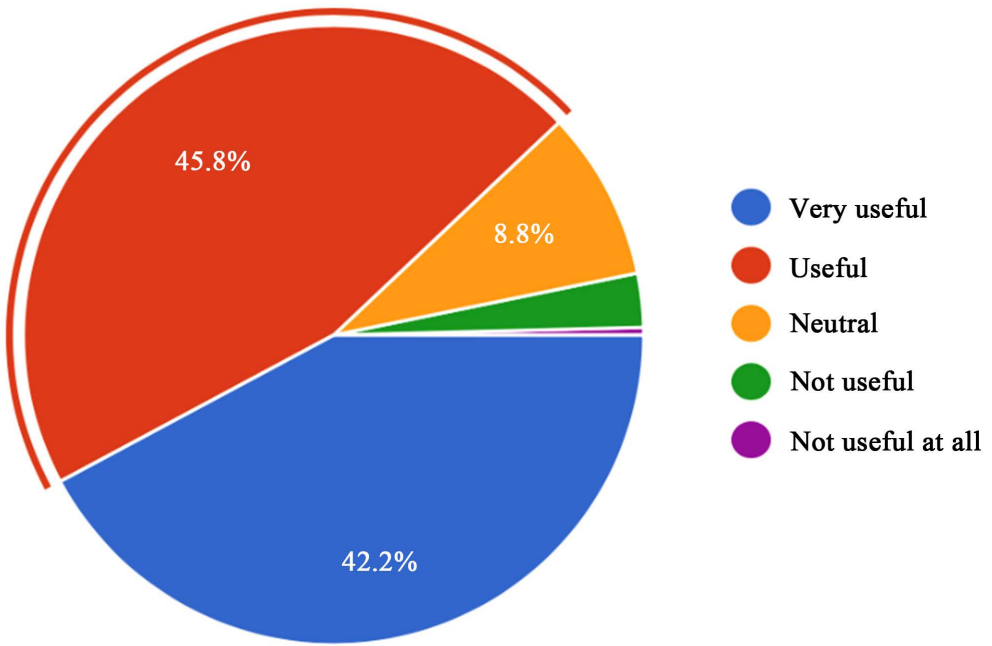

Figure 6. The answer for Q5.

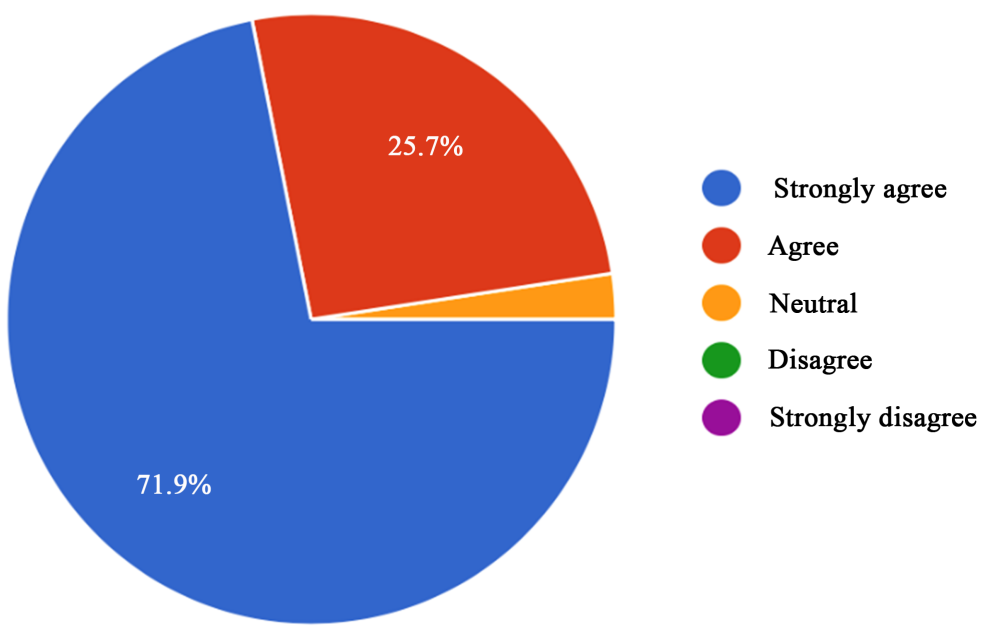

Figure 7. The answer for Q6. 


\section{Content Classification}

As mentioned earlier, all the tweets from one month are included in this analysis. We will classify the categories based on the topics discussed under the hashtag, along with an example of each category in Arabic as the source language and a back translation (BT) in English (see Table 1). Several tweets were retweeted or repeated several times, so they were excluded. As noticed from the sample, some twitter users send questions by direct messages instead of posting their question under the hashtag, while the hashtag users tend to post the received question-anonymously- with the hashtag to get the right and accurate answer from the crowd. A related point to consider is that the responses and comments on each tweet are not included within the results as they do not contain the hashtag. Hence, to read responses of any inquiry, users have to click on the tweet to display all the responses and comments, plus exporting the results in excel sheets do not include any further responses other that the main tweet that contains the hashtag. The source text includes only the main sentence and excludes the hashtags, links, and mentioned accounts.

Table 1 presents the overall classifications of the tweets' content. All the tweets in this paper are essentially under the same theme-language and translation. Compared to Dann's content classifications, which based mostly on previous studies, some sub-categories are inapplicable here; others are imbedded in the two main categories proposed by the author.

The main classification of the content is based on the nature of topics discussed in the tweets. The tweets either provide information, or demand information and help, or regardless of the type of information (sources, websites, etc.). Thus, the first main category is sharing information; this category involves all tweets from users who share the following translation-related information.

1) Events: This category includes information about translation events, such as conferences, workshops, training courses, translation initiatives, or even interview with professional translator via social media applications (e.g. Snapchat). Some of the workshops and training courses were free or online, and the tweets were advertising about the dates or providing feedback or thanks to the organizers of the events. The information about conferences was divided into three types: 1) advertising a conference; 2) sharing experiences of a particular conference; and 3) sharing terminologies and expressions used in a particular conference.

2) Information Sources: It also includes sharing information sources, including dictionaries, photos, pdf files of books and recommended books to read, reports/researches, and URLs. These can be URLs for language learning websites, websites to check if the book is translated or not, educational websites, videos, or reports.

3) Translation: It also includes shared translations of news, wisdoms and proverbs, terminologies, idioms (e.g. the top 50 idioms in a particular field with the translation), and Arabic translations of some phrases from other languages, such as Spanish and French. 
Table 1. Overview of categories and subcategories of the content.

\begin{tabular}{|c|c|c|}
\hline \multicolumn{3}{|c|}{ Category } \\
\hline \multicolumn{3}{|c|}{ 1. Sharing information } \\
\hline Subcategory & Example & BT \\
\hline \multirow{10}{*}{ 1.1. Events } & تقويم فعاليات ومؤتمرات الترجمة السمعبصرية 9 بـ ب. & $\begin{array}{l}\text { Activities calendar and } 2019 \text { audiovisual } \\
\text { translation conferences. }\end{array}$ \\
\hline & توصبات مؤتمر نيروبي لحقوق المترجمين ومسؤلياتهم من الونائق التي تبنتها & $\begin{array}{l}\text { Recommendations of the Nairobi Conference } \\
\text { The rights and responsibilities of translators } \\
\text { from documents adopted by UNESCO in } 1976 .\end{array}$ \\
\hline & !ورشة عمل مفيدة جدا & Very useful workshop \\
\hline & 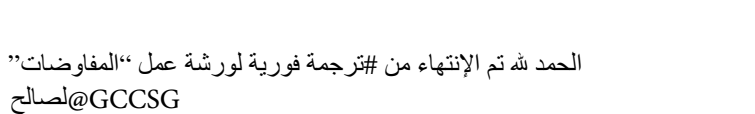 & $\begin{array}{l}\text { Praise be to Allah. Interpreting translation } \\
\text { of the Negotiations Workshop for GCCSG } \\
\text { has been completed. }\end{array}$ \\
\hline & Deputy Secretary General: نائب الأمين العام Assistant Secretary & Deputy Secretary General: نائب الأمين العام \\
\hline & General: أمين عام مساعد Disaster relief operations: & Assistant Secretary General: أمين عام مساعد \\
\hline & مساعدات غوثية : Relief assistant معليات غوث الكوارث & Disaster relief operations: عمليات غوث الكو ارث \\
\hline & للمترجمين تقدمه \#أكاديمية_المترجم CAT tools برنامج تدريبي مميز & $\begin{array}{l}\text { A great training program for CAT Tools for } \\
\text { translators provided by the translator's academy. }\end{array}$ \\
\hline & و هو طالب لُغات وترجمةXXاليوم ضيفنا على السناب الكترجم الفوري المُلهم & $\begin{array}{l}\text { Today our guest on Snapchat the inspiring } \\
\text { interpreter XX, a student of languages } \\
\text { and translation. }\end{array}$ \\
\hline & 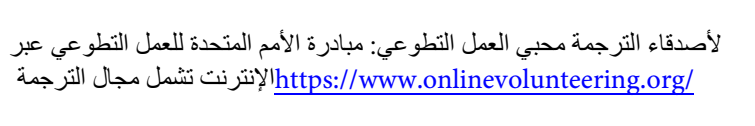 & $\begin{array}{l}\text { For translation friends who love volunteering: } \\
\text { The United Nations Voluntary Work } \\
\text { Initiative includes the translation domain. }\end{array}$ \\
\hline \multirow{7}{*}{$\begin{array}{l}\text { 1.2. Information } \\
\text { Sources }\end{array}$} & $\begin{array}{l}\text { http://my.vocabularysize.com/select/test } \\
\underline{\text { الختبروا حصيلتكم اللغوية في اللغة الإنليزية: }}\end{array}$ & Test your English vocabulary. [website] \\
\hline & $\begin{array}{l}\text { لا غنى لأي مترجم عن \#علوم_اللغة و هنا سلسلة شروح تتاسب جميع المستويات. } \\
\text { https://twitter.com/abuzare/status/951157954107133952 }\end{array}$ & $\begin{array}{l}\text { A translator is indispensable for \#language } \\
\text { science, and here is a series of annotations } \\
\text { that suits all levels. [website] }\end{array}$ \\
\hline & در اسة_حديثة_تؤكد-إمكانية-تعلم_لغة_أجنبية_جديدة_أثناء_النوم & $\begin{array}{l}\text { A recent study ensures the possibility of } \\
\text { leaning new foreign language while sleep. }\end{array}$ \\
\hline & 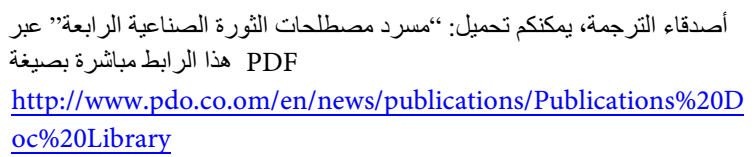 & $\begin{array}{l}\text { Friends of translation, you can download: } \\
\text { "Glossary of the Fourth Industrial Revolution" } \\
\text { through this link directly. [URL] }\end{array}$ \\
\hline & 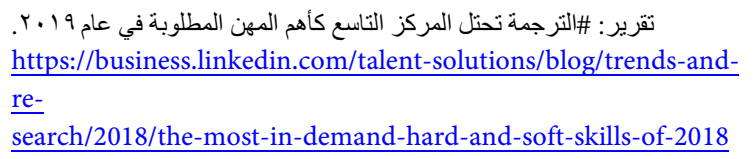 & $\begin{array}{l}\text { The Most In-Demand Hard and Soft Skills of } \\
\text { 2019|Linked In Talent Blog. [website] }\end{array}$ \\
\hline & $\begin{array}{l}\text { لكل من يسأل عن كيفية التأكد من ان الكتاب لم يترجم بعد: زيارة الموقع التالي //www.unesco.org/xtrans/ } \\
\text { http:/www }\end{array}$ & $\begin{array}{l}\text { For anyone who asks how to ensure that the } \\
\text { book has not yet been translated: visit [website] }\end{array}$ \\
\hline & 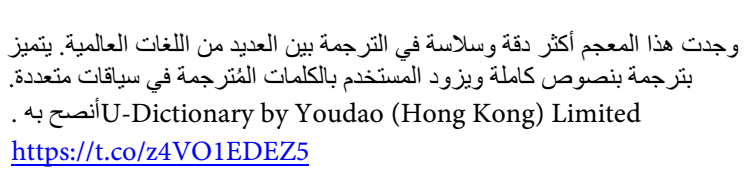 & $\begin{array}{l}\text { I found this glossary more accurate and smooth } \\
\text { translation between many of the world languages. } \\
\text { It features full-text translation and provides the } \\
\text { user with translated words in multiple contexts. } \\
\text { I recommend it. [link] }\end{array}$ \\
\hline
\end{tabular}




\section{Continued}

(Holistic translation planing by Nancy Pollini) 2) Localization standards reader 4.0 by David Filip. https://t.co/btiixFgKRU في مجال الثركات والأعمال: idioms أهم خمسين عبارة اصطلاحية https://www.topcorrect.com/blog/50-common-business-idioms/

مترجم: سوني بل ويليام نيوزلندي مسلم و أنشهر لاعب في رياضة الركبي، ينعي أسر \#NewZealandTerrorAttack \#Isالمترجم_في_خدمة_المترجم lamophobia \#TerrorismAgainstMuslims \#Haftrans https://t.co/0WHXdQ0Y1d

1.3. Translation

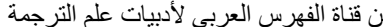

وتصوييها Transcreation نموذجان لأخطاء شائعة في الترجمة الإبداعية

I think this one wins the award for worst translation ever! (picture of wrong translation was posted)

1.5. Recommended Twitter Users

تم الحذف من قبل المؤلفه)تغريداتها مميزة (المترجمة حساب مميز للمهتمين بالترجمة

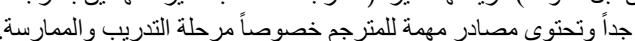

Beauty is in the eyes of the beholder للناس فيما يعشقون مذاهب.

I received my copy today, I recommend reading: 1) Holistic translation planning by Nancy Pollini

2) Localization standards reader 4.0 by David Filip

Proverb translation

The top fifty idioms in business and companies' field.

Translated: Sonny Bell William New Zealand Muslim and the most famous player in rugby sport, discourage the families of the martyrs in the \#Newzeland_terrorist attack.

[French expressions with Arabic translation]

[Spanish words originally from Arabic, with translation]

From the Arabic index of the of translation literature, two examples of common mistakes in creative translation are transcreation and corrections.

The post was in English

A special account for those interested in translation. Translator name (deleted by the author). Her tweets are very distinctive and contain important sources for the translator, especially the training and practice stage.

Great translation hashtags,

\#translation_phrases,

\#translator_sources,

عبار ات_المترجم \#مصادر_المترجم \#مهار ات_ترجمية \# وسوم ترجمية رائعة

\#translation_skills, Dear_translation_students,

\#transaltor_in_servant_translator,

\#Translator_morning.

Hashtags

\#transaltor_in-service transaltor FR

\#French call for a hashtag that gathers you, let it be the French version of the translators hashtag.

Required to work immediately:

- English translators.

- Promoters.

- holders of a diploma or bachelor's degree in the same specialization.

- Efficient and effective work is required.

2. Seeking Assistance
My GPA is 3.40 out of 5 , is there self-funded Master in translation? How much the cost?

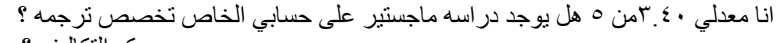

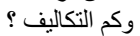




\begin{tabular}{|c|c|c|}
\hline & 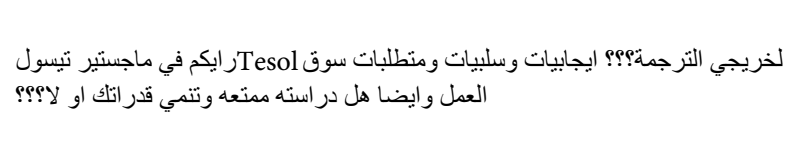 & $\begin{array}{l}\text { Your opinion in MA in TESOL for translation } \\
\text { graduates? Pros and cons and labor market } \\
\text { requirements, and is the study fun and } \\
\text { ability building or not? }\end{array}$ \\
\hline & 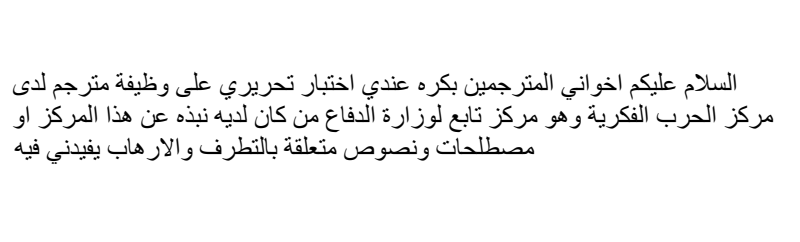 & $\begin{array}{l}\text { Salam, translators, tomorrow I have } \\
\text { written test for a translator job at the Center } \\
\text { for Intellectual War, a center of the Ministry } \\
\text { of Defense who has a profile of this center or } \\
\text { terms and texts related to extremism and } \\
\text { terrorism that benefit me. }\end{array}$ \\
\hline & عندي بحث تخرج أبغى اسوي وحاب يكون لفيلم وثائقي بس لازم ما يكون أنرجم قبل & $\begin{array}{l}\text { I have a graduation project, and I would } \\
\text { like to work on a documentary movie, } \\
\text { that have not been translated before. }\end{array}$ \\
\hline & $\begin{array}{l}\text { Hey! I'm working on a research paper on Simultaneous } \\
\text { Interpreting of Islamic discourse and this questionnaire } \\
\text { would help a lot. I'd be really grateful too if you } \\
\text { took the time and shared it with your colleagues. }\end{array}$ & A post in English-sharing a survey \\
\hline \multirow{3}{*}{$\begin{array}{l}\text { 2.2. Practice } \\
\text { Assistance }\end{array}$} & $\begin{array}{l}\text { How can I be a freelance translator?! How do I start? } \\
\text { I need your suggestions. }\end{array}$ & A post in English \\
\hline & تخرجت تخصص \#ترجمة وين ممكن أتدرب؟” أكثر سؤال بطرح & $\begin{array}{l}\text { I graduated with translating major where can } \\
\text { I train? The most asked question. }\end{array}$ \\
\hline & ج مطوني مقاطع حلوة اترجمها احس اثتقت اترجم بس مدري وش اترجم & $\begin{array}{l}\text { Give me nice clips to translate, I feel I miss } \\
\text { translation but don't know what to translate. }\end{array}$ \\
\hline \multirow[t]{2}{*}{ 2.3. Consultations } & 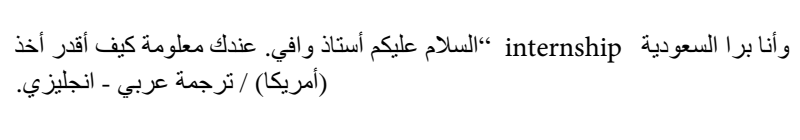 & $\begin{array}{l}\text { Salam Mr. Wafi, do you have information how } \\
\text { to get internship while I am outside Saudi } \\
\text { (U.S.A.) in translation Arabic to English. }\end{array}$ \\
\hline & 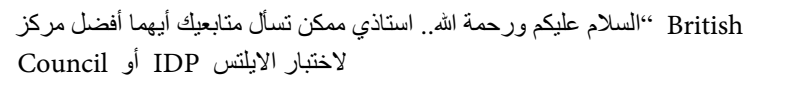 & $\begin{array}{l}\text { Salam Sir, can you ask your followers which one } \\
\text { is better, British Council or IDP for the IELTS? }\end{array}$ \\
\hline $\begin{array}{l}\text { 2.4. Information } \\
\text { Sources }\end{array}$ & $\begin{array}{l}\text { Is there any soft copy of this book "introducing interpreting } \\
\text { studies"? }\end{array}$ & A post in English \\
\hline \multirow{3}{*}{$\begin{array}{l}\text { 2.5. Translation } \\
\text { Assistance }\end{array}$} & 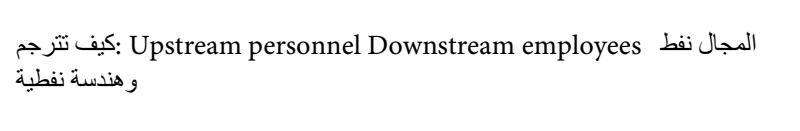 & $\begin{array}{l}\text { How to translate "Upstream personnel } \\
\text { Downstream employees" in Oil and } \\
\text { Petroleum engineering field. }\end{array}$ \\
\hline & هيلبب بليز الي عنده خلفية بالترجمهالقانوينه الله يسعدكم تكفون بس اخطأ فيهور يشتوف بس اذا & $\begin{array}{l}\text { Please help, anyone has a background in legal } \\
\text { translation, God bless you only } 4 \text { lines } \\
\text { check if there are any mistake.s }\end{array}$ \\
\hline & $\begin{array}{l}\text { أحتاج ترجمة لهذي الجملة، فاهنتها بس ماعرفت أصيغها بالعربي } \\
\text { Quick accessibility and well equipped with the skills and } \\
\text { knowledge In operating a computer would be very helpful for }\end{array}$ & $\begin{array}{l}\text { I need to translate this sentence; I can } \\
\text { understand it but cannot express it in Arabic. }\end{array}$ \\
\hline $\begin{array}{l}\text { 2.6. Translation } \\
\text { Assessment }\end{array}$ & 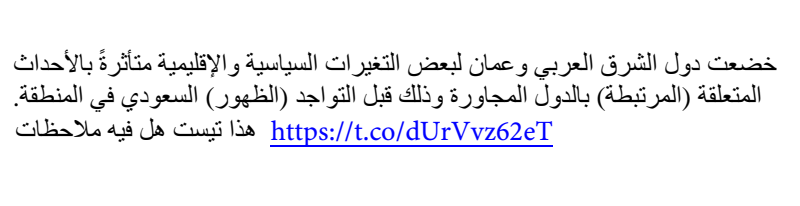 & $\begin{array}{l}\text { "The Arab countries of Oman and Oman } \\
\text { underwent some political and regional changes } \\
\text { influenced by events related to neighboring } \\
\text { countries before the Saudi presence in the region" } \\
\text { This is a test, are there any comments? }\end{array}$ \\
\hline 2.7. Experiences & 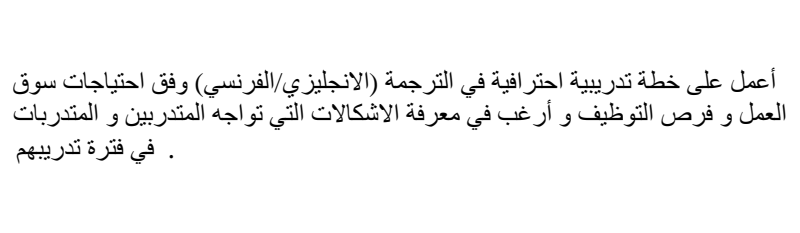 & $\begin{array}{l}\text { I work on a professional training program } \\
\text { in translation (English/French) according } \\
\text { to the needs of the labor market and } \\
\text { employment opportunities and I want to } \\
\text { know the problems faced by trainees } \\
\text { and trainees in their training period. }\end{array}$ \\
\hline
\end{tabular}


4) Incorrect Translation: It also includes shared pictures and URLs of incorrect translations, sometimes with corrections.

5) Recommended Twitter Accounts: It includes sharing information about useful or recommended accounts related to translation or TS.

6) Recommended Hashtags: It includes sharing information about translationrelated hashtags.

7) Vacancies: Sharing information about vacancies for translators, sometimes include links for the main source or website.

The second category of seeking assistance also has seven subcategories. Many users under this hashtag ask questions or ask for help with their translation, and the main subcategories include users asking for the following.

1) Academic Assistance: They ask for academic inquiries. Some users ask about particular programs (majors) to be enrolled in, topics for their dissertations, advice about TS in international and national universities, or about sharing their surveys to be completed by the hashtag users.

2) Practice Assistance: Some users post tweets to ask for short videos to practice translation, and some ask for other people to practice their English with via any application.

3) Consultations: They ask for consultations about the best learning centers for academic certificates such as IELTS and TOEFl.

4) Information Sources: They ask for information sources, such as books.

5) Translation Assistance: They ask for help in translating terminologies, phrases, or paragraphs.

6) Translation Assessments: They ask for feedback for their translations, sometimes for academic purposes where they have a translation assignment to be submitted, but they ask for the crowds' feedback.

7) Experiences: They request translators' experiences and problems in their profession to build up a training course.

Not all Dann's content classification [20] categories are involved in these two main categories, however, some are comprised. For example, Dann's conversational category that includes queries and responses matches the second category here with all the sub-categories under seeking assistance, though all the conversations in the hashtag are about translation or translation-related topics. While Dann's status category, applies to sharing information about events, where the tweets are about work, physical experiences, and activities. Pass along category also matches sharing information about information sources, Dann's "pass along" involves retweeting and user generated content or link to content by other users, the information sources shared under the hashtag are dictionaries, websites and reports. Finally, Dann's News category that includes headlines, sport news and event news, applies to sharing information by translation; where users share translated news, though the first category sharing information about events also involves news about events such as conferences and workshops related to translation. 


\section{Discussion and Conclusions}

The focus of this paper was to examine one particular Arabic hashtag for translators to crowdsource its users, their attitude toward this hashtag, and the content classifications of the tweets. As the results show, the users are translators, TS students, or freelancers. The hashtag serves fourteen Arab countries, and the majority is from Saudi Arabia. This confirms the 2017 Arab Social Media Report [21] that Saudi Arabia has the highest number of Twitter users among the Arab region, with around 2.6 million users, plus Twitter report that indicated $40 \%$ of active users in the Arab world are from Saudi Arabia. Another conceivable reason for this high number of Saudi Arabian users is that the founder of the hashtag is from-and lives in-Saudi Arabia. In addition to the large number of universities in Saudi Arabia, 28, translation is available as a major in bachelor's or master's degrees [22]. However, starting this initiative from one country and extending it to thirteen other countries is promising and confirms the users' attitudes toward this hashtag. Their answers reveal their positive attitudes toward all hashtags in general, and this is confirmed by the increasing number of Arabic hashtags serving translators and translations, such as المترجم [translator], المبار ات_المترجم [translator's_phrases], مهارات_ترجمية [translational_skills], عزيزي-طالب_الترجمة [dear_translation_student], and many others. Moreover, the content revealed the creation of Arab hashtags to serve translators for languages other than English, such as French. The suggestion was to add the initial FR after the existing hashtag المترجم_في_خدمة_المترجم to target only translators to/from French.

The content classifications of the tweets revealed the importance of this hashtag in sharing and seeking information. Involving users with PhDs' and master's degrees along with specialists in translation, or even professional translators, makes this professional community a trustworthy and reliable source to gain the required information, to discuss and share translation related issues, or to exchange academic and professional experiences.

Finally, the field of social media and crowdsourcing in general, and Twitter and hashtags specifically, is a significant topic that attracted several studies from different regions. Unfortunately, the studies in this field in the Arab region, compared to other regions, are very limited. Considering the short term of this study and the chosen hashtag, several investigations can be obtained from the selected target. For future studies, the information-seeking behavior of Arab translators and a further examination of the information sources they share online will be explored.

\section{Conflicts of Interest}

The author declares no conflicts of interest regarding the publication of this paper.

\section{References}

[1] Gamal, M. (2007) Audiovisual Translation in the Arab World: A Changing Scene. Translation Watch Quarterly, 3, 78-95.

[2] Desjardins, R. (2017) Translation and Social Media in Theory. In: Training and in 
Professional Practice, Palgrave Pivot, London, 95-120.

https://doi.org/10.1057/978-1-137-52255-9_5

[3] Snell-Hornby, M. (2012) From the Fall of the Wall to Facebook. Translation Studies in Europe Twenty Years Later. Perspectives, 20, 365-373.

https://doi.org/10.1080/0907676X.2012.702403

[4] Cornin, M. (2013) Translation in the Digital Age. Routledge, New York.

[5] Desjardins, R. (2013) Translation and Social Media. In: Gambier, Y. and Doorsler, L., Eds., Handbook of Translation Studies, John Benjamins, Amsterdam, 156-159. https://doi.org/10.1075/hts.4.soc3

[6] Persaud, A. (2017) Quality and Acceptance of Crowdsourced Translation of Web Content. International Journal of Technology and Human Interaction, 13, 100-115. https://doi.org/10.4018/IJTHI.2017010106

[7] Hossain, M. and Kauranen, I. (2015) Crowdsourcing: A Comprehensive Literature Review. Strategic Outsourcing: An International Journal, 8, 2-22. https://doi.org/10.1108/SO-12-2014-0029

[8] Twitter (2018) How to Use a Hashtag? https://help.twitter.com/en/using-twitter/how-to-use-hashtags

[9] Huberman, B., Romero, D.M. and Wu, F. (2008) Social Networks that Matter: Twitter under the Microscope. https://doi.org/10.2139/ssrn.1313405 https://papers.ssrn.com/sol3/papers.cfm?abstract_id=1313405

[10] Broersma, M. and Graham, T. (2013) Twitter as a News Source. Journalism Practice, 7, 446-464. https://doi.org/10.1080/17512786.2013.802481

[11] Zhao, W.X., Jiang, J., Weng, J.S., He, J., Lim, E.-P., Yan, H.F. and Li, X.M. (2011) Comparing Twitter and Traditional Media Using Topic Models. In: Advances in Information Retrieval: 33rd European Conference on IR Research, Dublin, Ireland, 18-21 April 2011, Springer Verlag, Berlin.

[12] Twitter (2018) Twitter, Our Services, and Corporate Affiliates. https://help.twitter.com/en/rules-and-policies/twitter-services-and-corporate-affiliates

[13] Dubai School of Government (2014) Arab Social Media Report. http://www.arabsocialmediareport.com/Twitter/LineChart.aspx?\&PriMenuID=18\& CatID $=25 \& \mathrm{mnu}=\mathrm{Cat}$

[14] Carter, S., Tsagkias, M. and Weerkamp, W. (2011) Twitter Hashtags: Joint Translation and Clustering. In: Proceedings of 2011 ACM Web Science, ACM, New York, 1-3.

[15] Small, T. (2011) What the Hashtag? A Content Analysis of Canadian Politics on Twitter. Information, Communication and Society, 14, 872-895. https://doi.org/10.1080/1369118X.2011.554572

[16] Koetsier, J.S. (2013) Are \#Hashtags Geeky? 71\% of Social Media Users Say No. https://venturebeat.com/2013/03/27/are-hashtags-geeky-71-of-social-media-users-s ay-no

[17] Xiao, F., Noro, T. and Tokuda, T. (2014) Finding News-Topic Oriented Influential Twitter Users Based on Topic Related Hashtag Community Detection. Journal of Web Engineering, 13, 405-429.

[18] Vaismoradi, M. (2013) Content Analysis and Thematic Analysis: Implications for Conducting a Qualitative Descriptive Study. Nursing and Health Sciences, 15, 398-405. https://doi.org/10.1111/nhs.12048

[19] Kim, H., Jang, S.M., Kim, S.-H. and Wan, A. (2018) Evaluating Sampling Methods for Content Analysis of Twitter Data. Social Media+ Society, 4, 1-10. https://doi.org/10.1177/2056305118772836 
[20] Dann, S. (2010) Twitter Content Classification. First Monday, 15. https://doi.org/10.5210/fm.v15i12.2745 https://firstmonday.org/ojs/index.php/fm/article/view/2745/2681\%2C

[21] Salem, F. (2017) The Arab Social Media Report 2017: Social Media and the Internet of Things: Towards Data-Driven Policymaking in the Arab World. MBR School of Government, Dubai.

[22] Ministry of Education-Higher Education Statistics Center (2016) Higher Education Institutions in the Kingdom of Saudi Arabia.

https://departments.moe.gov.sa/PlanningDevelopment/RelatedDepartments/Educat ionstatisticscenter/EducationDetailedReports/Pages/default.aspx 